\title{
Effects of Aframomun Chrysanthum Seed Aqueous Extract Against Acetaminophen-induced Liver Toxicity in Rats
}

\author{
Nwachoko Ndidi ${ }^{1, ~ *, ~ E s s i e n ~ E k a ~ B a s s e y ~}{ }^{2}$, Ayalogu Edward Obiozo ${ }^{3}$ \\ ${ }^{1}$ Department of Biochemistry, Rivers State University, Nkpolu-Oroworukwo, Port Harcourt, Nigeria \\ ${ }^{2}$ Department of Biochemistry, University of Port Harcourt, Choba, Nigeria \\ ${ }^{3}$ Department of Medical Biochemistry, Rivers State University, Nkpolu-Oroworukwo, Port Harcourt, Nigeria
}

Email address:

blessedconfidence@yahoo.com (N. Ndidi)

*Corresponding author

\section{To cite this article:}

Nwachoko Ndidi, Essien Eka Bassey, Ayalogu Edward Obiozo. Effects of Aframomun Chrysanthum Seed Aqueous Extract Against Acetaminophen-induced Liver Toxicity in Rats. Advances in Biochemistry. Vol. 7, No. 1, 2019, pp. 1-4. doi: 10.11648/j.ab.20190701.11

Received: April 11, 2019; Accepted: May 23, 2019; Published: June 5, 2019

\begin{abstract}
Plants and their components are the only source of most drugs which comprise of distinct groups such as antispasmodics, emetics, anticancer and antimicrobials. Plants capable of improving health conditions and treating diseases have been identified and used since human existence. A wide variety of compound synthesized from plants participate in biological roles such as defense against predators. This study examined the protective effect of Aframomunchrysanthum seed aqueous extract against acetaminophen-induced liver toxicity in rats. A suspension of $750 \mathrm{mg} / \mathrm{kg}$ acetaminophen was administered once every 72 hours to induce toxicity in the rats. This was followed by oral administration of the plant extract $(500,1000$ and $2000 \mathrm{mg} / \mathrm{kg}$ ) body weight and $100 \mathrm{mg} / \mathrm{kg}$ of silymarine. For ten days. Eighteen hours after the last dosage, blood sample was collected for biochemical analysis. The result showed significant $(p<0.05)$ increase in the activities of aspartate aminotransferase (AST), alanine aminotransferase (ALT) and alkaline phosphatase (ALP) as well as the concentrations of albumin (ALB) and total bilirubin (T. B) levels in rats administered with acetaminophen only. The levels of these parameters were significantly $(\mathrm{p}<0.05)$ decreased in the groups pretreated with the extract.
\end{abstract}

Keywords: Aframomun Chrysanthum, Silymarine, Hepatoprotective

\section{Introduction}

Plants have been known worldwide to be source of large amount of drugs, comprising of different groups [1-2]. Owing to the outbreak of different diseases and microbial resistance to some available drugs, proper identification and evaluation of plants have been encouraged [1-2]. There have been claims worldwide by the traditional system that some plants possessed medicinal properties [1-2]. Chemicals in plants (phytochemicals) are compound that naturally occur in plants [1-2]. These components are important for the various plants activities [1-3]. It is now believed that nature has given the cure of every disease in one way or another [1-2]. Thus modern researchers/ researches are designed toward evaluation and characterization of plants and plant components.

The largest organ in the body is the liver; it fulfills a number of tasks that are relevant to our body system [4]. Its major function is to examine and screen blood from the digestive tract before allowing its passage to other parts of the body [4-5]. The liver along with the pancreas, and intestines work together- digest, absorb and process food and foreign materials [4-6]. It is the major site for biotransformation and highly susceptible to the poisonous effect of foreign substances that affect living organism [4-5]. Directly, it receives blood from the gastrointestinal tract which makes it particularly susceptible to damage by ingested toxicant $[4,6]$. Toxicity to the liver due to drugs and chemicals causing liver disease is largely due to the active metabolite they produce [6]. Early warning symptoms that indicate its imbalance/ malfunction are difficult to note and a person may unknowingly suffer for a long time from a liver disorder without knowing it [4-6]. 


\section{Materials and Methods}

\subsection{Plant Material}

Aframomum chrysanthum seeds (AC) was obtained from Ekuku-Agbor in Ika South Local Government of Delta State, Nigeria. The name of the plant was confirmed by O. B. Green of the Department of Plant Science and Biotechnology, Rivers State University, NkpoluOroworukwo, Port Harcourt, Nigeria.

\subsection{Sample Preparation}

The seeds of AC were air dried and ground to powder. Extraction was carried out with warm distilled water in the ratio of $1 \mathrm{~g}$ to $5 \mathrm{ml}$. The plant was soaked for 30 minutes and filtered using Whatman No. 1 filter paper and also with a funnel plunged with glass wool [7-8]. The residues of the plantwas re-extracted in warm distilled water for same duration and filtered. The filtrates were pooled together with the previous ones and concentrated with a water bath at $50^{\circ} \mathrm{C}$. The concentrated form of the sample was stored at $4^{0} \mathrm{C}$ until needed [9-10]. Stock solution of the concentrated plant sample was constituted with distilled water at concentration of $500 \mathrm{mg} / \mathrm{ml}$ and different doses $(500,1000$ and $2000 \mathrm{mg} / \mathrm{kg})$ were prepared.

\subsection{Experimental Animals}

Wistar albino rats weighing between $150-200 \mathrm{~g}$ were used in this study. The rats were acclimatized for one week prior to the commencement of the experiment. The animals were housed under standard laboratory conditions of light and dark cycles of 12 hours and were provided with rodent pellet food and water ad libitum. The animals were categorized into control and experimental groups.

\section{Result}

Table 1. Protective effect of pretreatment with aqueous extract of Aframomunchrysanthum seeds on enzyme markers of tissue damage in acetaminophen induced toxicity.

\begin{tabular}{|c|c|c|c|c|}
\hline Group & Treatment & $\operatorname{AST}(\mathbf{u} / \mathbf{l})$ & $\operatorname{ALT}(u / l)$ & $\operatorname{ALP}(u / l)$ \\
\hline 1 & Control & $34.75 \pm 4.5 \mathrm{a}$ & $14.75 \pm 0.5 \mathrm{a}$ & $36.50 \pm 5.0 \mathrm{a}$ \\
\hline 2 & Acetaminophen $750 \mathrm{mg} / \mathrm{kg}$ & $103.00 \pm 2.0 \mathrm{~b}^{*}$ & $29.25 \pm 1.0 b^{*}$ & $57.75 \pm 4.5 b^{*}$ \\
\hline 3 & Silymarin $100 \mathrm{mg} / \mathrm{kg}$ & $93.00 \pm 4.24 \mathrm{bc}$ & $17.25 \pm 0.5 \mathrm{a}^{* \mathrm{c}}$ & $34.50 \pm 3.0 \mathrm{a}^{* \mathrm{c}}$ \\
\hline 4 & $500 \mathrm{mg} / \mathrm{kg}$ Extract & $42.25 \pm 15.64 \mathrm{a}^{* \mathrm{~d}}$ & $15.75 \pm 2.5 \mathrm{a}^{* \mathrm{c}}$ & $52.50 \pm 5.7 \mathrm{bd}$ \\
\hline 5 & $1000 \mathrm{mg} / \mathrm{kg}$ Extract & $40.25 \pm 0.5 \mathrm{a}^{* \mathrm{~d}}$ & $15.25 \pm 0.5 \mathrm{a}^{* \mathrm{c}}$ & $45.25 \pm 2.1 \mathrm{a}^{* \mathrm{~d}}$ \\
\hline 6 & $2000 \mathrm{mg} / \mathrm{kg}$ Extract & $44.00 \pm 3.92 \mathrm{a}^{* \mathrm{~d}}$ & $17.00 \pm 0.0 \mathrm{a}^{* \mathrm{c}}$ & $35.75 \pm 2.4 \mathrm{a}^{* \mathrm{c}}$ \\
\hline
\end{tabular}

Key: $\mathrm{AST}=$ aspartate aminotransferase, $\mathrm{ALT}=$ alanine aminotransferase, $\mathrm{ALP}=$ alkaline phosphatase.

Values are mean \pm standard deviations of $n=4$ determinations. Values in each column with different superscript letter $(a, b)$ differ significantly when comparing Group 1 and other Groups (2, 3, 4, 5 and 6), values with superscript $(*)$ differ significantly when comparing Group 2 with other Groups (3, 4, 5 and 6) and values with different superscript letter (c, d) differ significantly when comparing Group 3 with 4, 5 and 6 at 5\% level $\mathrm{p}<0.05$.

Table 2. Protective effect of pretreatment with aqueous extract of Aframomunchrysanthum seeds on non enzyme markers of tissue damage in acetaminophen induced toxicity.

\begin{tabular}{|c|c|c|c|c|c|c|c|c|c|}
\hline Group & Treatment & $\begin{array}{l}\text { T. C } \\
(\mathrm{mmol} / \mathrm{l})\end{array}$ & $\begin{array}{l}\text { T. G } \\
(\mathrm{mmol} / \mathrm{l})\end{array}$ & $\begin{array}{l}\text { HDL } \\
(\mathrm{mmol} / \mathrm{l})\end{array}$ & $\operatorname{ALB}(g / l)$ & $\begin{array}{l}\text { T. B } \\
(\mu \mathrm{mol} / \mathrm{l})\end{array}$ & $\begin{array}{l}\text { C. B } \\
(\mu \mathrm{mol} / \mathrm{l})\end{array}$ & $\%$ PCV & T. P (g/l) \\
\hline 1 & Control & $3.75 \pm 0.2^{\mathrm{a}}$ & $1.42 \pm 0.1^{\mathrm{a}}$ & $2.10 \pm 0.4^{\mathrm{a}}$ & $37.25 \pm 1.0 \mathrm{a}$ & $9.75 \pm 0.9^{\mathrm{a}}$ & $6.62 \pm 0.6^{\mathrm{a}}$ & $35.50 \pm 0.6^{\mathrm{a}}$ & $96.75 \pm 2.9^{\mathrm{a}}$ \\
\hline 2 & Acetaminophen $750 \mathrm{mg} / \mathrm{kg}$ & $3.80 \pm 0.4^{\mathrm{a}^{*}}$ & $1.15 \pm 0.8^{\mathrm{a} *}$ & $1.90 \pm 0.2^{\mathrm{a} *}$ & $50.75 \pm 1.0^{\mathrm{b} *}$ & $14.52 \pm 1.3^{\mathrm{b} *}$ & $3.32 \pm 0.6 \mathrm{~b}^{*}$ & $41.75 \pm 0.5 b^{*}$ & $78.25 \pm 5.2^{\mathrm{b} *}$ \\
\hline 3 & Silymarin $100 \mathrm{mg} / \mathrm{kg}$ & $3.37 \pm 0.1^{\mathrm{ac}}$ & $1.05 \pm 0.1^{\mathrm{ac}}$ & $2.07 \pm 0.2^{\mathrm{ac}}$ & $38.50 \pm 0.6^{\mathrm{a} * \mathrm{c}}$ & $9.75 \pm 0.9^{\mathrm{a} * \mathrm{c}}$ & $5.8 \pm 1.2^{\mathrm{a} * \mathrm{c}}$ & $44.75 \pm 1.0^{\mathrm{b} * \mathrm{c}}$ & $83.50 \pm 5.0^{\mathrm{bc}}$ \\
\hline 4 & $500 \mathrm{mg} / \mathrm{kg}$ Extract & $1.77 \pm 0.4^{\mathrm{b} * \mathrm{~d}}$ & $0.75 \pm 0.1^{\text {ac }}$ & $0.97 \pm 0.3^{\mathrm{b} * \mathrm{~d}}$ & $34.25 \pm 1.0 \mathrm{a}^{* \mathrm{~d}}$ & $13.25 \pm 0.5^{\text {bd }}$ & $9.15 \pm 0.8^{\mathrm{b}^{* \mathrm{~d}}}$ & $41.00 \pm 1.2^{\mathrm{bd}}$ & $80.50 \pm 2.9^{\mathrm{bc}}$ \\
\hline 5 & $1000 \mathrm{mg} / \mathrm{kg}$ Extract & $2.60 \pm 0.1^{\mathrm{b} * \mathrm{~d}}$ & $0.70 \pm 0.1^{\mathrm{ac}}$ & $0.80 \pm 0.2^{\mathrm{b} * \mathrm{~d}}$ & $33.50 \pm 2.4^{\mathrm{b} * \mathrm{~d}}$ & $5.12 \pm 1.0^{\mathrm{b} * \mathrm{~d}}$ & $3.02 \pm 0.7^{\mathrm{bd}}$ & $41.25 \pm 1.5^{\mathrm{bd}}$ & $79.00 \pm 1.2^{\mathrm{bc}}$ \\
\hline 6 & $2000 \mathrm{mg} / \mathrm{kg}$ Extract & $3.15 \pm 0.1^{\mathrm{b} * \mathrm{c}}$ & $0.75 \pm 0.1^{\mathrm{ac}}$ & $1.00 \pm 0.2^{\mathrm{b} * \mathrm{~d}}$ & $36.50 \pm 2.4^{\mathrm{a} * \mathrm{c}}$ & $9.30 \pm 0.0^{\mathrm{a} * \mathrm{c}}$ & $5.32 \pm 1.4^{\mathrm{ac}}$ & $41.00 \pm 1.2^{\mathrm{bd}}$ & $77.25 \pm 1.5^{\mathrm{bc}}$ \\
\hline
\end{tabular}

Key: T. $\mathrm{C}=$ total cholesterol, $\mathrm{T} . \mathrm{G}=$ total glyceride, $\mathrm{HDL}=$ high density lipoprotein, $\mathrm{ALB}=$ albumin, $\mathrm{T} . \mathrm{B}=$ total bilirubin, $\mathrm{C} . \mathrm{B}=$ conjugated bilirubin, $\mathrm{PCV}$ $=$ packed cellvolume, T. P total protein.

Values are mean \pm standard deviations of $\mathrm{n}=4$ determinations. Values in each column with different superscript letter $(a, b)$ differ significantly when comparing Group 1 and other Group (2, 3, 4, 5 and 6), values with superscript $(*)$ differ significantly when comparing Group 2 with other Group (3, 4 and 5) and values with different superscript letter (c, d) differ significantly when comparing Group 3 with 4, 5 and 6 at $5 \%$ level $p<0.05$.

\section{Discussion}

Management of hepatic disease is based on some parameters/ objectives: treat the specific cause of the disease, attend to the metabolic consequences of reduced hepatic function, facilitate hepatocellular regeneration and impede the progression of hepatic injury and pathological changes $[11,5]$. A variety of markers are used in the assessment of response to medical treatment [12-13]. 
Serum amino transferase (AST), alanine aminotransferase and alkaline phosphatase (ALP) are markers used to assess the level of recovery to the damaged organ. A decline in the serum activity of these enzymes usually indicates recovery. Serum albumin is clinically a useful marker of hepatic synthetic function [12-14]. The ability of a drug or supplement to reduce injurious effect or preserve the normal hepatic physiological mechanisms, which have been disturbed by a hepatoxin, is the index of its protective effect. Hepatoprotective/ameliorative effect of plant drugs and herbal formulations are studied against chemicals and drugs hepatotoxicity in experimental animals, as they mimic any form of naturally occurring liver disease [15].

Results of the effect of pretreatment with aqueous extract of Aframomum chrysanthum seeds on enzyme markers of tissue damage in acetaminophen-induced toxicity in albino rats are shown in Table 1. Liver enzymes (ALT, AST, and ALP) were low in control rats. Injury to the liver results in the release of these enzymes into the blood. An increased level of these enzymes indicates hepatic necrosis. This Table presented the values of these enzymes in the pretreated and non pretreated groups. Comparing the values of these enzymes in group 1 (control) and group 2 (induced without pretreatment), Group 2 values were significantly ( $p$ $<0.05$ ) higher than the values of group1. This increase in the values of these enzymes in group 2 indicated liver damage to the rats by acetaminophen thus the elevated values. Also activities of these enzymes in Group 2 when compared to those in and groups 4, 5 and 6 (groups pretreated with 500, 1000 and $2000 \mathrm{mg} / \mathrm{kg}$ Aframomumchrysanthum), showed a significant $(\mathrm{p}<0.05)$ decrease in the values of these enzymes in the pretreated groups. This significant $(\mathrm{p}<0.05)$ reduction in the values of these enzyme markers in the pretreated groups showed that AC extract has hepatoprotective activity.

The protective activity of these plants could be attributed to the phytochemicals present in the plants. Silymarin (reference drug) is known to protect the hepatic cell by acting on the cell membrane, stabilizing and protecting the liver against deleterious agent. It directs action to liver cells, protect the membrane integrity, stabilize and strengthens membranes of cell organs and nuclei in the cells to prevent mutation and death. Qualitative and quantitative phytochemical analysis of AC has shown that the plant contains flavonoids [16]. Silymarin is a flavonoid, which is present in AC. This silymarin may have acted in the same way with that in the reference drug, thus conferring protective activity to the liver.

Table 2 shows the impact of pretreatment with aqueous extract of AC seeds on non-enzyme markers of tissue damage in acetaminophen induced toxicity in rats. The results show a reduction in the lipid profile of rats in the Groups pretreated with AC extract. TG and HDL values of the Groupspretreated with the extract were statistically different at $\mathrm{p}<0.05$ when compared with rats in Groups 1and 2. Also the result of the liver function test revealed that total bilirubin and albumin values were significantly $(\mathrm{p}<0.05)$ higher in group 2 (without pretreatment) than the groups pretreated with $\mathrm{AC}$ extract and reference drug. This result showed a reduction in lipid profile values of the pretreated groups and a significant increase the values of T. B ALB of the non pretreated group.

The observed decrease in the lipid profile of rats in the pretreated Groups (Table 2) with the extracts could be attributed to the activities of some of the phytochemicals present in the plant. Saponinshave the ability to bind with lipids, forming micelles which enhances easy excretion, thus a reduction in the lipid values Also there was significant $(\mathrm{p}<$ 0.05 ) increase in the albumin and total bilirubin values in the non pretreated Group. This reflects the depth of pathophysiology of the liver and one of the most sensitive and useful ways to substantiate the functional integrity of the liver and the severity of hepatonecrosis. Therefore the significant increase in the T. B and ALB values of the non pretreated group confirm the degree of damage to the liver of the rats.

\section{Conclusion}

The study has shown that aqueous extract of Aframomun chrysanthum seed possessed hepatoprotective properties against acetaminophen induced toxicity.

\section{Acknowledgements}

Authors are grateful to management of Lively Stone Medical Diagnostic Laboratory, Choba, Rivers State.

\section{References}

[1] Lichterman, B. L. (2004). Aspirin: the story of a wonder drug. British medical Journal, 329 (7479): 1408.

[2] Tapsell, L. C., Hemphill, I. and Cabiac, L. (2006). Health benefits of herbs and spices, the past present and future. Medicinal Journal of Australia, 185 (4): 54 - 24.

[3] Fabricant, D. S., and Farnsworth, H. R. (2001). The value of plants used in traditional medicine for drug discovery. Environmental Health Perspective, 109 (1): 69-75.

[4] Dorland's, D. (2012). Dorland's illustrated Medical Dictionary. $32^{\text {nd }}$ edition. Elsevier. p. 285.

[5] Abdel-Misih, M., Sherif, R. Z. and Bloomston, M. (2010). Liver anatomy. Surgical Clinics of North America, 90 (40): 643-653.

[6] Gupta, S. K. and Singhvi, I. J. (2011). Herbal and hepatoprotective drugs acting on peptic ulcer and liver disease. International Journal of Pharmacy and Technology, 3: 824 853.

[7] Bakare, R. I., Magbagbeola, O. A., Akinwande, A. I., Okunowo, O. W. and Green, M. (2011). Antidiarrhoeal activity of aqueous leaf extract of Momordicacharantiain rats. Journal of Pharmacognosy and Phototherapy, 3 (1): 1-7. 
[8] Lapanik, B., Prosok, M. and Wondra, A. G. (2005). Comparison of extracts prepared from plant by-product using different solvents and extraction time. Journal of Food Engineering, 71: 214-222.

[9] Oben, J. E., Assi, S. E., Agbor, G. B. and Musoro, D. F. (2006). Effect of Eremomastaxspecidsaon experimental diarrhea. African Journal of Traditional Complement, 3 (1): $95-100$

[10] Handa, S. S., Khanuja, S. P. S., Longo, G. and Rakesh, D. D. (2008). Extraction technologies for medicineal and aromatic plants. International centre medicinal for and aromatic plants. International centre for science and high technology, Trieste, 21-25.

[11] Maton, A., Jean, H., Charles, W. M., Susan, J., Maryanna, Q. W., David, L. And Jill, D. W. (1993). Human Biology and Health. Englewood Cliffs, New Jersey, USA. p 13.

[12] Friedman, L. S., Martin, P. and Munoz, S. J. (1996). Liver function tests and the objective evaluation of the patient with liver disease. In Zakin, D, Boyer, T. D. eds. Hepatology: A Textbook of Liver Disease, $3^{\text {rd }}$ ed. Philadelphia, W. B. Saunders. P 791 - 833.

[13] Sturgill, J. R. and Lumbert, M. G. L. (1997). Medicinal plants of Lauras novas. Fitoterapia, 56: $515-520$

[14] Ezeonwu, V. U. and Dahiru, D. (2013). Protective effect of biherbal formulation of Ocimum gratissimum and Gongronema latifolium aqueous leaf extract on acetaminophen- induced hepato- nephrotoxicity in rats. American Journal of Biochemistry, 3 (1): 18-23.

[15] Weber, L. W., Boll, M. and Stampfl, A. (2003). Hepatotoxicity and mechanism of action of haloalkanes: Carbontetrachloride as toxicological model. Critical Review and Toxicology, 33: $105-136$.

[16] Nwachoko, N., Essien, E. B. and Ayalogu, E. O. (2015). Proximate and Quantitative phytochemical analysis of Aframomumchrysanthum. Open Access Library Journal, 2: e1529 (1-5). 